\title{
Spominu prof. dr. Petra Andraschkeja
} (1939-2020)

Festival Ljubljana in Slovenski glasbeni dnevi se spominjamo dolgoletnega sodelavca, prijatelja in znanstvenika, prof. dr. Petra Andraschkeja, ki je v sredo, 25. marca, sklenil svojo bogato življenjsko pot.

Rojen je bil 1. decembra $1939 \mathrm{v}$ šlezijskem Bielitzu (Bielsko), študiral je muzikologijo v Freiburgu, ter germanistiko v Münchnu, Berlinu in Freiburgu. Bil je asistent in nato privatni docent na univerzi v Freiburgu. Doktoriral je $\mathrm{z}$ delom »Kompozicijski proces in analiza Mahlerjeve 9. simfonije« (izšlo 1976), ki sodi med temeljna dela za razumevanje Mahlerjevega načina komponiranja. Pomemben je bil njegov prispevek (habilitacija) na temo »Folklora in zunajevropska umetna glasba $\mathrm{v}$ delih avantgarde $\mathrm{v} 2 \mathrm{O}$. stoletju« (1981). Od leta 1988, pa vse do upokojitve, leta 2005, je bil profesor za glasbeno zgodovino na univerzi v Gießnu. Rad je prihajal v Slovenijo in je od leta 1986 tesno sodeloval pri organizaciji Slovenskih glasbenih dnevov v Ljubljani in jim ostal do konca zvest. Še za letošnji simpozij v Ljubljani je pripravil in oddal referat »Schönbergov odnos do popularne glasbe: opereta, vokalna in instrumentalna glasba«. Bil je zaželen in priljubljen sodelavec na številnih kongresih in simpozijih po vsej Evropi. V svojih prispevkih se je vedno rad vračal k razmerju med glasbo in poezijo, med glasbo in govorico.

Spominjali se ga bomo po njegovem velikem znanju, zvestem prijateljstvu in izjemni družabnosti. Po upokojitvi se je leta 2007 preselil v Perch- 
toldsdorf blizu Dunaju, kjer je preživel zadnja leta svojega življenja, obenem pa uspešno nadaljeval svoje delo na Centru Arnold Schönberg.

\section{Počivaj v miru - dragi prijatelj!}

\section{Darko Brlek \\ Primož Kuret}

\section{Prof. Dr. Peter Andraschke - referati na SGD}

1986: Pesnitev in glasba. Ustvarjalna izmenjava $\mathrm{k}$ Mahlerjevim in Webernovim uglasbitvam Bethgeja

1987: Ključna dela. Dostopi do nove glasbe

1988: „Saloma« Slavka Osterca - Minutna opera kot eksperiment

1989: Folklora in kompozicija

1991: Izbor in obdelava besedil v Gallusovi zbirki Moralia

1992: Beraška opera. Socialni angažma glasbenega gledališča

1993: Nova glasba: začetek in eksperiment, tradicija in provokacija

1994: Karlheinz Stockhausen in začetki elektronske glasbe. Predpostavke, ozadja, sprejem

1995: Med zabavo, vzgojo in poskusi. Opombe h glasbi v nemškem radiu

2o-tih let

1996: Igor Stravinski in vizualne umetnosti

1997: Spravni Requiem na koncu drugega tisočletja

1998: Bohuslav Martinů: glasba zoper vojno in razdejanje

2004: Iskanje identitete: »Musica Ricercata« Györya Ligetia

2005: Hugo Wolf: Eolska harfa

2006: »...peti na prostem.« O družabni vokalni glasbi Fanny

in Felixa Mendelssohna

2007: Svetovna glasba K. Stockhausna

2008: Suite 1922 - O konceptih P. Hindemitha in A. Schönberga

2009: Maurizio Kagel: Mare nostrum

2010: Ojdip, tiran Carla Orffa. Glasbeno gledališče v duhu antičnega mita

2011: Glasbeno slovo Gustava Mahlerja

2012: Kompozicijska imaginacija narave pri Antonu Webernu 
2013: The Rake's Progress. Recepcijski momenti pri Stravinskem, Hagartu in Audenu

2014: Arnold Schönberg, konservativni revolucionar

2015: Proces komponiranja in analiza - pomembna tema simpozijev

2016: Egon Wellesz na Dunaju in v Oxfordu. Postaje življenja

2018: Raznolikost moderne. Glasbeni dnevi v Donaueschingenu in Baden-Badnu v 20. letih 20. stoletja 2019: Stara in nova glasba v praksi ter poučevanje na Univerzi in Visoki šoli za glasbo v Freiburgu i. Br.

2020: Schönbergov odnos do popularne glasbe: opereta, vokalna in instrumentalna glasba 